\title{
Degree of moisture in seeds for the cryopreservation of orchids native to Brazil
}

\section{Edilene Aparecida Preti Ferrari ${ }^{1}$ (i) Ronan Carlos Colombo ${ }^{(i)}$ Ricardo Tadeu de Faria $^{3^{*}}$ (i) Carmen Silvia Vieira Janeiro Neves $^{3}$ Franciele da Silva Vero ${ }^{3}$}

${ }^{1}$ Instituto de Desenvolvimento Rural do Paraná Iapar-Emater, Santo Antônio da Platina, PR, Brasil.

${ }^{2}$ Departamento de Ciências Agrárias, Universidade Tecnológica Federal do Paraná (UTFPR), Francisco Beltrão, PR, Brasil.

${ }_{3}^{3}$ Departamento de Agronomia, Universidade Estadual de Londrina (UEL), 86057-970, Londrina, PR, Brasil. E-mail: faria@uel.br. ${ }^{*}$ Corresponding author.

ABSTRACT: The objective of this study was to determine the ideal moisture degree for the cryopreservation of Cattleya labiata Lindl. and Miltonia regnellii Rchb.f. orchid seeds. Orchid seeds were standardized in relation to the desired moisture degrees (4, 6, 8, 10, 12, and 15\%) and were subjected to rapid freezing in liquid nitrogen $\left(-196^{\circ} \mathrm{C}\right)$ for $24 \mathrm{~h}$; then, the seeds were defrosted and analyzed. For both orchid species, the seeds that were immersed in liquid nitrogen with 4\% moisture content had the highest viability percentage, averaging $95 \%$ and $68 \%$ of viable seeds for C. labiata and M. regnellii, respectively. The seeds with $12 \%$ and $15 \%$ moisture content had no viable seeds. For the fresh mass of seedlings, there was no significant difference between moisture content treatments for either species.

Key words: liquid nitrogen, freezing, survival, Cattleya labiata Lindl., Miltonia regnellii Rchb.f.

Grau de umidade para criopreservação de sementes de orquídeas nativas do Brasil

RESUMO: $O$ objetivo deste trabalho foi determinar o grau de umidade ideal para criopreservação das sementes das orquideas Cattleya labiata Lindl. e Miltonia regnelli Rchb.f.. As sementes das orquideas foram padronizadas em relação aos graus de umidade desejados (4, $6,8,10,12$ e 15\%) e submetidas ao congelamento rápido em nitrogênio líquido $\left(-196^{\circ} \mathrm{C}\right)$ durante 24 horas; em seguida, descongeladas e analisadas. O maior percentual de viabilidade, tanto para as sementes de C. labiata quanto para M. regnelli, ocorreu quando as sementes foram imersas em nitrogênio líquido com 4\% de umidade, atingindo 95 e $68 \%$ de sementes viáveis, respectivamente, sendo que, as sementes com 12 e 15\% de umidade não apresentaram sementes viáveis. Em relação à massa fresca de plântula, não houve diferença entre os tratamentos (grau de umidade)para as espécies avaliadas.

Palavras-chave: Nnitrogênio líquido, congelamento, sobrevivência, Cattleya labiata Lindl., Miltonia regnelii Rchb.f..

\section{INTRODUCTION}

In order to achieve success in the ex situ conservation of orchid germplasms, it is necessary to know the structural and physiological changes that can happen in the seeds when subjected to a reduction in the degree of moisture and stored at low temperatures. Orchid seeds are classified as orthodox, and as such, are physiologically affected by storage conditions, including those of cryopreservation (PRITCHARD \& SEATON, 1993; PRITCHARD et al., 1999; PRITCHARD \& PRENDERGAST, 1989).

Cryopreservation is a technique that can be used to store plant material without a time limit, since it reduces metabolism to levels so low that all biochemical processes are practically paralyzed (KARTHA, 1985). Some advantages of the technique are the small space occupied by a germplasm bank maintained in liquid nitrogen, the simplicity of handling the material, and the low investment cost, since it does not require a cooling system and electricity (ALMEIDA et al., 2002).

The techniques used in the cryopreservation of plants are controlling the rate of refrigeration, vitrification, encapsulation, dehydration, and dormant buds' preservation (REED, 2008). These techniques can promote the simultaneous storage of different parts of the studied plant. In orchid seeds, 
the vitrification technique has shown a greater potential for tolerating the stress caused by the action of cryopreservation (MERRITT, 2014; SUZUKI et al., 2018). However, before proceeding with this technique, it is important to study the performance of seeds under different degrees of moisture.

The critical point of cryopreservation is the degree of moisture in the seeds that have gone through this process, because if there is little water in their tissues, they will suffer from excessive dehydration and will not survive. Conversely, if there is a large amount of water, there will be the formation of ice crystals inside the cells that can cause the membranes to rupture, resulting in cell death (VENDRAME et al., 2014).

For freezing, it is agreed that the maximum moisture limit (Limit Moisture Content for Cryopreservation - LMCC) is adopted, above which the viability of a seed sample is reduced during the freezing process. According to the author, this critical limit is usually a relatively narrow range of moisture degrees within a species, but it can vary between species (STANWOOD, 1985).

In seeds of Cattleya aurantiaca (Bateman ex Lindl.), PRITCHARD \& SEATON (1993) observed a reduction in their longevity at $5{ }^{\circ} \mathrm{C}$ when stored with moisture degree above and below 5\%. However, in a study with 16 species of orchids, ALVAREZ-PARDO \& FERREIRA (2006) were successful in storing seeds with a moisture content of $6 \%$ at $-18{ }^{\circ} \mathrm{C}$, with seed viability maintained after 24 weeks. In this context, the objective of the study was to determine the ideal degree of moisture for the cryopreservation of Cattleya labiata Lindl. and Miltonia regnellii Rchb.f. orchid seeds.

\section{MATERIALS AND METHODS}

The trials were carried out at the Cryopreservation Laboratory located at Department of Agronomy of the State University of Londrina (UEL). Cattleya labiata and Miltonia regnellii, orchids growing at Orquidário UEL, were artificially pollinated to obtain the capsules and seeds. With the aid of a scalpel, the mature capsules were dissected to extract seeds, and it were kept in paper bags at a temperature of $4{ }^{\circ} \mathrm{C}$ until the beginning of trials.

To start the trials, the moisture degree of the seeds was determined and their physiological quality was evaluated by means of germination and tetrazolium tests. This was achieved by adapting the methodologies recommended in the Seed Analysis Rules (BRASIL, 2009), as will be described below.
The initial moisture degree content in the seeds was obtained using the gravimetric method, where seeds were dried in an oven at $105+3{ }^{\circ} \mathrm{C}$ for 24 hours to measure the water mass removed from the seeds by drying. For that, the arithmetic mean of four subsamples of $0.001 \mathrm{~g}$ of seeds was calculated.

Thus, it was found that the initial degree of moisture in the seeds of $C$. labiata was $9 \%$ and of $M$. regnellii was $8 \%$. After determining the initial moisture degree in the seeds, they were subjected to the drying process in an oven or increased humidity in an airtight glass container until they reached the moisture degrees required to compose the six treatments $(4,6,8,10,12$, and $15 \%$ moisture). For each moisture degree, $0.004 \mathrm{~g}$ of seeds were used, with the amount of water extracted or absorbed determined by the equation:

$P_{f}=P_{i}\left(\frac{100-T A_{i}}{100-T A_{f}}\right)$

where: $P_{f}=$ final sample mass, $\mathrm{g} ; P_{i}=$ initial sample mass, g; $T A_{i}=$ initial moisture degree of seeds; $T A_{f}=$ desired seeds moisture degree.

To increase the seeds moisture degree, the seed samples were placed in small baskets made with a PVC ring and a 150-thread weave silk screen, which were placed inside an airtight glass container containing $50 \mathrm{~mL}$ of distilled water. Then, the containers were placed in an oven at $25^{\circ} \mathrm{C}$ and the samples were weighed every $6 \mathrm{~h}$ until they reached the desired moisture degrees.

For drying, the seed samples were placed in an oven at a temperature of $25-27^{\circ} \mathrm{C}$ until they reached the masses that referred to the desired moisture degrees, and were weighed in an electronic scale with an accuracy of $0.0001 \mathrm{~g}$. Then, seeds were separated according to the moisture degree defined for each treatment and were stored in cryotubes, which were subjected to freezing in a cryogenic tank containing liquid nitrogen $\left(-196^{\circ} \mathrm{C}\right)$.

After 24 hours of freezing, seeds were subjected to rapid thawing in a water bath at 40 ${ }^{\circ} \mathrm{C}$ for 1.5 minutes, and two subsamples of seeds were removed. A subsample was submitted to the tetrazolium test to evaluate the percentage of viable seeds. In the tetrazolium test, the seeds were initially soaked for $24 \mathrm{~h}$ in distilled water at $25^{\circ} \mathrm{C}$, then immersed in an aqueous solution of $1 \%$ tetrazolium salt (2,3,5 triphenyl tetrazolium chloride) and kept in the absence of light at $30{ }^{\circ} \mathrm{C}$ for $24 \mathrm{~h}$. Seeds were then counted under the steric microscope Motic, and the seeds with red colored embryos were considered viable (LAUZE et al., 1994). 
To calculate the percentage of viable seeds, empty seeds (without an embryo) were not considered. At the beginning of the experiment, the viability of the seeds of $C$. labiata was $98 \%$, while the viability of the seeds of $M$. regnellii was $47 \%$.

The other subsample of the seeds was used to perform the germination test. The seeds were arranged for germination in MS medium (MURASHIGE \& SKOOG, 1962), with half the concentration of macronutrients and the $\mathrm{pH}$ corrected with potassium hydroxide $(\mathrm{KOH})$ to 5.8 . The $\mathrm{MS}$ medium was distributed in glass flasks $(40 \mathrm{~mL} /$ flask), which were closed with a plastic cap and then sterilized in an autoclave at a pressure of $105 \mathrm{~kg} \mathrm{~cm}^{-2}$ and a temperature of $121^{\circ} \mathrm{C}$ for $30 \mathrm{~min}$ (FARIA et al., 2012). Before sowing, $10 \mathrm{mg}$ of seeds from each lot were disinfected in sodium hypochlorite solution $(0.5 \%)$ for $15 \mathrm{~min}$ in a laminar flow chamber, then rinsed with distilled water and sterilized in an autoclave. Then, 10 $\mathrm{mg}$ of seeds were added to $10 \mathrm{~mL}$ of distilled water; 1 $\mathrm{mL}$ of this mixture was removed and applied over the MS medium. The flasks were then capped and sealed with PVC plastic film. The flasks were placed in a growth room with a temperature of $25^{\circ} \mathrm{C}$, a photoperiod of $16 \mathrm{~h}$ and illuminance of $120 \mu \mathrm{mol} \mathrm{s}{ }^{-1} \mathrm{~m}^{-2}$ from fluorescent lamps for approximately 120 days. Ten flasks were sown for each batch of seeds.

After 90 days, the protocorms (which originated from the seeds) were subcultured in the MS medium, which was modified with half the concentration of macronutrients (1/2 MS). After 150 days, the percentage survival of the protocorms, the fresh and dry mass of the seedlings, and the number of shoots formed in the C. labiata seedlings were determined.

The experimental design was completely randomized with six treatments (degrees of moisture) and 10 replicates, with $10 \mathrm{mg}$ of seeds per treatment. The data were submitted to an analysis of variance and the means were compared by the Tukey test at $5 \%$.

\section{RESULTS AND DISCUSSION}

After rapid defrosting, each seed lot was divided into two subsamples, one used for the tetrazolium test and the other for the germination test. From the tetrazolium test, the viable seeds had a red color, indicating that the embryo had active metabolic activity, and were able to germinate and develop into a new seedling (Figure 1). Samples that were shown to be viable by the tetrazolium test were subjected to the in vitro germination test.
Among the degrees of moisture studied in the seeds of C. labiata, it was reported that the seeds immersed in liquid nitrogen with $4 \%$ moisture content showed the highest percentage of viability, reaching 95\%. As the seed moisture degree increased, a reduction in viability was observed by the tetrazolium test; the $10 \%$ moisture degree was responsible for a viability of $62 \%$. Miltonia regnellii seeds with $4 \%$ moisture content also had the highest percentage of viability, reaching, on average, $68 \%$, followed by those with $6 \%, 8 \%$ and $10 \%$ moisture, with $53 \%$, $19 \%$ and $13 \%$ viability, respectively. In both the $C$. labiata and $M$. regnellii lots, seeds that had $12 \%$ and $15 \%$ moisture content did not present viable seeds after defrosting (Table 1).

Regarding the percentage survival of the protocorms at 150 days, there was no statistical difference among treatments, with survival ranging from $96 \%$ to $100 \%$ for C. labiata and from $82 \%$ to $100 \%$ for M. regnellii (Table 1).

The seedling fresh mass showed no difference among the evaluated species. The values ranged from $0.052 \mathrm{~g}$ to $0.077 \mathrm{~g}$ for C. labiata, and from $0.014 \mathrm{~g}$ to $0.026 \mathrm{~g}$ for $M$. regnellii. In the seedlings of $C$. labiata, the highest dry mass was obtained in the treatment with seeds that had $6 \%$ moisture before freezing, which was significantly higher than seeds with $10 \%$ moisture degree; however, it did not differ from the other treatments. In the seedlings of $M$. regnellii, the value of the treatment with $6 \%$ moisture degree was superior to the treatment with $8 \%$ but did not differing statistically from the other treatments (Table 2).

Due to differences in the development of the two species, it was only possible to evaluate the number of shoots in C. labiata seedlings. For this characteristic, the average values ranged from 1.22 to 1.38 shoots per seedling; however, these did not differ statistically between treatments (Table 2).

Recovering cryopreserved seeds with high viability is of fundamental importance to prove the efficiency of an adopted method. The tetrazolium test was efficient in evaluating the viability of the seed and made it possible to obtain results quickly and efficiently. This test has also been used successfully to evaluate the seeds of other cryopreserved orchids, as demonstrated by HIRANO et al. (2005), VENDRAME et al. (2014), HIRANO et al. (2011), PAULA et al. (2018) and SUZUKI et al. (2018).

The first studies on freezing orchid seeds for storage were carried out using temperatures ranging from -10 to $-40{ }^{\circ} \mathrm{C}$ and demonstrated that it 

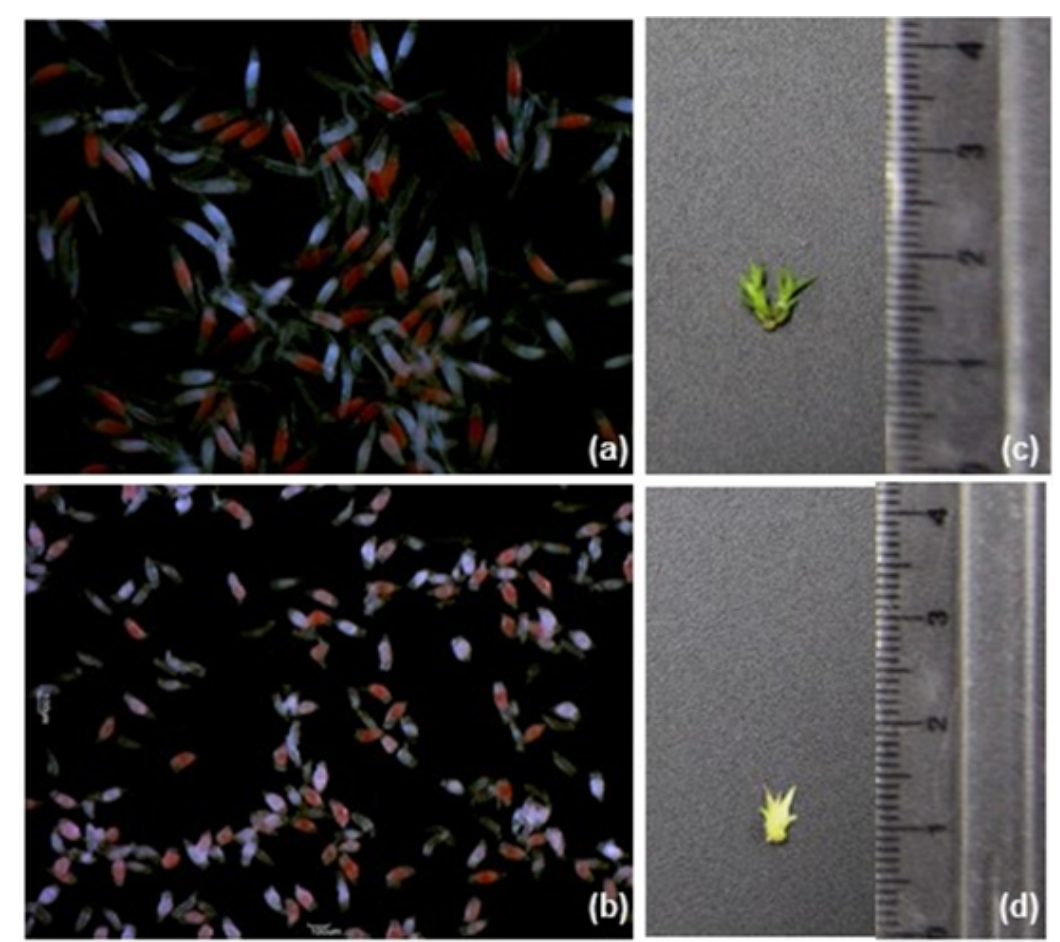

Figure 1 - Seeds with 4\% moisture cryopreserved in liquid nitrogen and subjected to the tetrazolium test: Cattleya labiata Lindl. (a) and Miltonia regnellii Rchb.f. (b); a seedling from seeds with $4 \%$ moisture subjected to cryopreservation in liquid nitrogen then subcultured after $150 \mathrm{~d}$ : C. labiata (c) and $M$. regnellii (d).

was possible to obtain viable seeds after defrosting; however, due to the seeds being previously dehydrated, increasing storage time caused a reduction and even the total loss of viability of these seeds (KOOPOWITZ, 2001; BOWLING \& THOMPSON, 1972). In some species, PRITCHARD (1986) observed that when stored at $-10{ }^{\circ} \mathrm{C}$, all seeds lost viability in eight years.

Thus, in relation to seed storage and conservation, orchids are similar to species that have orthodox seeds, since the longevity of the seeds is increased by reducing the moisture degree (from about $20 \%$ wet basis to $5 \%$ ) and decreasing storage temperatures from $62{ }^{\circ} \mathrm{C}$ to $0{ }^{\circ} \mathrm{C}$ (PRITCHARD \& SEATON, 1993; MACEDO et al., 2014).

In trials performed with seven species of Brassicaceae at different temperatures and moisture degrees, ESTRELLES \& GONZALES-BENITO (2015) concluded that there was great variation for ideal storage conditions among species, and that for most species the storage of seeds with high moisture degrees was problematic.
Traditional methods of storing orchid seeds would be problematic if used; for example, in a seed bank. However, at ultra-low temperatures, the results are promising, both in orchids and in other species. In Pistacia vera L. seeds, a maximum of $90 \%$ germination was obtained after $8 \mathrm{~h}$ of drying on silica gel (which corresponded to $11.7 \%$ moisture degree) and direct immersion in liquid nitrogen; while in the seeds of Pistacia terebinthus and P. lentiscus, when the moisture degree was reduced to about $20 \%$, germination rates of $16 \%$ and $47 \%$ were obtained, respectively (OZDEN-TOKATLI et al., 2007).

Studies have shown that the ideal moisture degree in seeds for freezing at ultra-low temperatures can vary according to genera and species. The cryopreservation of Doritis pulcherrima orchid seeds with $31 \%$ of moisture in liquid nitrogen resulted in $0 \%$ germination after defrosting (THAMMASIRI, 2000). On the other hand, WANG et al. (1998), obtained $88 \%$ viability after cryopreservation of Dendrobium candidum seeds in liquid nitrogen, with 12 to $19 \%$ moisture. 
Table 1 - The percentage of viable seeds (VS) of Cattleya labiata Lindl. and Miltonia regnellii Rchb.f., with different moisture degrees determined by the tetrazolium test after cryopreservation in liquid nitrogen, and the percentage survival of protocorms originating from the cryopreserved seeds after 150 days of subculture (PS). Values given are averages.

\begin{tabular}{|c|c|c|c|c|}
\hline \multirow[t]{2}{*}{ Moisture degree (\%) } & \multicolumn{2}{|c|}{------------------Cattleya labiata Lindl.----------------- } & \multicolumn{2}{|c|}{---------------Miltonia regnellii Rchb.f.---- } \\
\hline & $\operatorname{VS}(\%)^{* *}$ & PS $(\%)$ & VS $(\%)^{* * *}$ & PS (\%) \\
\hline 4 & $95 \mathrm{a}^{*}$ & $97 a^{*}$ & $68 \mathrm{a}^{*}$ & $88 \mathrm{a}^{*}$ \\
\hline 6 & $88 \mathrm{~b}$ & $100 \mathrm{a}$ & $53 \mathrm{~b}$ & $100 \mathrm{a}$ \\
\hline 8 & $69 \mathrm{c}$ & $96 \mathrm{a}$ & $19 \mathrm{c}$ & $82 \mathrm{a}$ \\
\hline 10 & $62 \mathrm{~d}$ & $100 \mathrm{a}$ & $13 \mathrm{c}$ & 93 a \\
\hline 12 & - & - & - & - \\
\hline 15 & - & - & - & - \\
\hline $\mathrm{CV} \%$ & 5.49 & 5.57 & 30.05 & 25.07 \\
\hline
\end{tabular}

* Averages followed by the same lower-case letters in the column do not significantly differ by the Tukey test at $5 \%$.

${ }^{* *}$ Initial viability of $C$. labiata seeds $=98 \%$.

${ }^{* * *}$ Initial viability of $M$. regnellii seeds $=47 \%$.

In most cases, when the moisture degree was lower, between $4 \%$ and $6 \%$, the possibility of obtaining viable seeds is greater, which was in agreement with SAKAI et al. (1991) when they stated that one of the most important steps in cryopreservation is the dehydration process, because it aims to prevent physical damage by the formation of ice crystals to the cells during the freezing period. In view of this information, some authors recommend the use of cryoprotective solutions in order to dehydrate the seeds, thus reducing the negative effects of the formation of ice crystals during the freezing process (VENDRAME et al., 2014; PAULA et al., 2018; SUZUKI et al., 2018). However, the use of cryoprotective solutions becomes costly and some components of these solutions can exert toxicity on the orchid's seeds, leading to the death of the embryo. Therefore, it would be more beneficial to reduce the degree of moisture in the seeds using physical processes before freezing, such as drying in ovens with forced air circulation.

\section{CONCLUSION}

The moisture degree that resulted in the highest frequency of viable $C$. labiata and $M$. regnellii seeds is $4 \%$. Seeds of the aforementioned cryopreserved species with a moisture degree greater than $8 \%$ showed a marked reduction in their viability and germination potential.

Table 2 - Fresh mass (g) (FM) and dry mass (g) (DM) of Cattleya labiata and Miltonia regnellii seedlings, and the number of shoots (NS) of $C$. labiata from seeds with different moisture degrees that were cryopreserved in liquid nitrogen.

\begin{tabular}{|c|c|c|c|c|c|}
\hline \multirow[t]{2}{*}{ Moisture degree (\%) } & \multicolumn{5}{|c|}{----------------Cattleya labiata Lindl.----------------- } \\
\hline & FM (g) & DM (g) & NS & FM (g) & $\mathrm{DM}(\mathrm{g})$ \\
\hline 4 & $0.073 \mathrm{a}$ & $0.006 \mathrm{ab}$ & $1.37 \mathrm{a}$ & $0.024 \mathrm{a}$ & $0.0027 \mathrm{ab}$ \\
\hline 6 & $0.077 \mathrm{a}$ & $0.007 \mathrm{a}$ & $1.22 \mathrm{a}$ & $0.026 \mathrm{a}$ & $0.0034 \mathrm{a}$ \\
\hline 8 & $0.052 \mathrm{a}$ & $0.005 \mathrm{ab}$ & $1.38 \mathrm{a}$ & $0.014 \mathrm{a}$ & $0.0022 \mathrm{~b}$ \\
\hline 10 & $0.052 \mathrm{a}$ & $0.004 \mathrm{~b}$ & $1.29 \mathrm{a}$ & $0.022 \mathrm{a}$ & $0.0027 \mathrm{ab}$ \\
\hline 12 & - & - & - & - & - \\
\hline 15 & - & - & - & - & - \\
\hline CV\% & 34.62 & 30.06 & 38.13 & 46.03 & 31.46 \\
\hline
\end{tabular}

${ }^{*}$ Averages followed by the same lower-case letters in the column do not significantly differ by the Tukey test at $5 \%$. 


\section{ACKNOWLEDGEMENTS}

The authors acknowledge the financial support given by Coordenação de Aperfeiçoamento de Pessoal de Nível Superior (CAPES) and Conselho Nacional de Desenvolvimento Científico e Tecnológico (CNPq).

\section{DECLARATION OF CONFLICT OF INTERESTS}

The authors declare no conflict of interest. The founding sponsors had no role in the design of the study; in the collection, analyses, or interpretation of data; in the writing of the manuscript, and in the decision to publish the results.

\section{AUTHORS' CONTRIBUTIONS}

EAPF, RCC and RTF conceived and designed experiments. EAPF, RCC and FSV performed the experiments and carried out the lab analyses. EAPF, RCC, RTF and CSVJN prepared the draft of the manuscript. All authors critically revised the manuscript and approved of the final version.

\section{REFERENCES}

ALMEIDA, F. A. C. et al. Cryoconservation of nordestina and pernambucana varieties of castor bean seeds. Revista Brasileira de Engenharia Agrícola e Ambiental, v.6, n.2, p.295-302, 2002. Available from: <https://www.scielo.br/pdf/rbeaa/v6n2/ v6n2a19.pdf $>$. Accessed: Mar. 01, 2017. doi: 10.1590/S141543662002000200019 .

ALVAREZ-PARDO, V.; FERREIRA, A. G. Orchid seed storage. Revista Brasileira de Sementes, v.28, n.1, p.92-98, 2006. Available from: <https://www.scielo.br/pdf/rbs/v28n1/ a13v28n1.pdf $>$. Accessed: Feb. 28, 2017. doi: 10.1590/S010131222006000100013 .

BOWLING, J. C.; THOMPSON, P. A. On storing orchid seed. Orchid Review, v.80, p.120-121, 1972.

BRASIL. Ministério da Agricultura, Pecuária e Abastecimento. Regras para análise de sementes. Secretaria de Defesa Agropecuária. Brasília: MAPA/ACS, 2009. 395p. Available from: $<$ https://www.abrates.org.br/files/regras_analise_de_sementes. pdf $>$. Accessed: Sep. 26, 2019.

FARIA, R.T. et al. Produção de Orquídeas em Laboratório. Londrina: Mecenas, 2012. 124p.

HIRANO, T. et al. Wide applicability of cryopreservation with vitrification method of seeds of some Cymbidium species. Plant Biotechnology, v.28, p.99-102, 2011. Available from: <https://www. jstage.jst.go.jp/article/plantbiotechnology/28/1/28_10.1115a/_ pdf $>$. Accessed: Mar. 01, 2017. doi: 10.5511/ plantbiotechnology.10.1115a.

HIRANO, T. et al. Cryopreservation of immature seeds of Bletilla striata by vitrification. Plant Cell Reports, v.23, p.534539, 2005. Available from: <https://www.ncbi.nlm.nih.gov/ pubmed/15565321>. Accessed: Mar. 06, 2017. doi: 10.1007/ s00299-004-0893-9.
KARTHA, K. K. Meristem culture and germplasm preservation. In: KARTHA, K.K. Cryopreservation of plant cells and organs. Florida: CRC Press, 1985. p.115-134.

KOOPOWITZ, H. Orchids and their conservation. Portland, Oregon: Timber Press, 2001. 177p.

LAUZER, D. et al. Tetrazolium staining and in vitro germination of mature seeds of Cypripedium acaule (Orchidaceae) Lindleyana. Palm Beach, v.9, n.3, p.197-204, 1994. Available from: <http:// www.academia.edu/13279752/Tetrazolium staining and in vitro_germination_of_mature_seeds_of_Cypripedium_acaule_Orchidaceae>. Accessed: Feb. 15, 2017.

MACEDO, M. C. et al. Seed storage and acclimatization of Brassavola tuberculata Hook. Semina: Ciências Agrárias, v.35, n.6, p.2883-2894, 2014. Available from: <http:// www.uel.br/revistas/uel/index.php/semagrarias/article/ download/11261/15399>. Accessed: Sep. 16, 2019. doi: 10.5433/1679-0359.2014v35n6p2883.

MIRA, S. et al. Effect of water content and temperature on seed longevity of seven Brassicaceae species after 5 years of storage. Plant Biology, v.17, p.153-162, 2015. Available from: <https:// www.ncbi.nlm.nih.gov/pubmed/24804799>. Accessed: Mar. 01, 2017. doi: 10.1111/plb.12183.

MERRITT, D. J. et al. Ex situ Conservation and Cryopreservation of Orchid Germplasm. International Journal of Plant Sciences, v.175, n.1, p.46-58, 2014. Available from: <https://www.journals. uchicago.edu/doi/10.1086/673370>. Accessed: Jun. 06, 2019. doi: 10.1086/673370.

MURASHIGE, T.; SKOOG, F. A revised medium for rapid growth and bioassays with tobacco tissue cultures. Physiologia Plantarum, v.15, p.473-497, 1962. Available from: <https:// onlinelibrary.wiley.com/doi/abs/10.1111/j.1399-3054.1962. tb08052.x>. Accessed: Sep. 26, 2019. doi: 10.1111/j.13993054.1962.tb08052.x.

OZDEN-TOKATLI, Y. et al. Cryopreservation of Pistacia spp. seeds by dehydratation and one-step freezing. Cryo Letters, v.28, n.2, p.83-94, 2007. Available from: <https://www.ncbi.nlm.nih. gov/pubmed/17522727>. Accessed: Mar. 08, 2017.

PAULA, J. C. B. et al. Cryoprotectant solutions in star orchid seeds and bamboo orchid conservation in liquid nitrogen. Ornamental Horticulture, v.24, n.4, p.341-346, 2018. Available from: <https:// www.scielo.br/pdf/oh/v24n4/2447-536X-oh-24-04-0341.pdf>. Accessed: Jun. 01, 2019. doi: 10.14295/oh.v24i4.1180.

PRITCHARD, H. W. Orchid seed storage at the Royal Botanic Gardens, Kew, England. 2. Physiology Unit, Wakehurst Place. Orchid Research Newsletter, v.7, p.18, 1986.

PRITCHARD, H. W.et al. Interespecific variation in orchid seed longevity in relation to ultra-dry storage and cryopreservation. Lindleyana, v.14, n.2, p.92-101, 1999. Available from: <https:// eurekamag.com/research/003/181/003181646.php $>$. Accessed: Mar. 6, 2017.

PRITCHARD, H. W.; PRENDERGAST, F. G. Factors influencing the germination and storage of orchid pollen. In: PRITCHARD, H.W. Modern methods in orchid conservation: the role of physiology ecology and management. Cambridge: Cambridge University Press, 1989. p.1-16. 
PRITCHARD, H. W.; SEATON, P. T. Orchid seed storage: historical perspective, current status, and future prospects for long-term conservation. Selbyana, v.14, p.89-104, 1993. Available from: <https://www.jstor.org/stable/41760422?seq=1\#page_scan_ tab_contents $>$. Accessed: Mar. 7, 2017.

REED, B. M. Cryopreservation - practical considerations. In: REED, B.M. Plant Cryopreservation: A Practical Guide. New York: Springer, 2008, p.3-14.

SAKAI, A. et al. Survival by vitrification of nucelar cells of navel orange (Citrus sinensis Osb.var. brasiliensis Tanaka) cooled to -196․ Journal Plant Physiology, v.137, p.465-470, 1991.

STANWOOD, P. C. Cryopreservation of seed germplasm for genetic conservation In: KARTHA, K. K. Cryopreservation of plant cells and organs. Boca Rotan: CRC Press, 1985, p.199-225.

SUZUKI, A. B. P. et al. Seed cryopreservation of the endangered Brazilian orchid Cattleya granulosa Lindl. Iheringia, Série
Botânica, v.73, n.2, p.146-150, 2018. Available from: <https://isb. emnuvens.com.br/iheringia/article/view/465/441>. Accessed: Jun. 6, 2019. doi: 10.21826/2446-8231201873206.

THAMMASIRI, K. Cryopreservation of seeds of a Thai orchid (Doritis pulcherrima Lind.) by vitrification. Cryo Letters, v.21, p.237-244, 2000. Available from: <https://www.ncbi.nlm.nih.gov/ pubmed/12148041>. Accessed: Feb. 20, 2017.

VENDRAME, W. A. et al. Orchid Cryopreservation. Ciência e Agrotecnologia, v.38, n.3, p.213-229, 2014. Available from: $<$ http://www.scielo.br/pdf/cagro/v38n3/01.pdf $>$. Accessed: Feb. $15,2017$.

WANG, J. $\mathrm{H}$ et al. Cryopreservation of seeds and protocorms of Dendrobium candidum. Cryo Letters, v.19, p.123-128, 1998. Available from: <https://www. researchgate.net/publication/279670815 Cryopreservation of seeds_and_protocorms_of_Dendrobium_candidum $>$. Accessed: Mar. 16, 2017. 